\title{
Post-diagnosis serum insulin-like growth factors in relation to dietary and lifestyle changes in the Prostate testing for cancer and Treatment (ProtecT) trial
}

\author{
Vanessa Er $^{1,2}$ (D) Kalina Biernacka ${ }^{2,3} \cdot$ Andrew J. Simpkin ${ }^{1,4} \cdot$ Richard M. Martin $^{1,2,4}$ • \\ Mona Jeffreys $^{1} \cdot$ Pauline Emmett $^{1} \cdot$ Rebecca Gilbert $^{1} \cdot$ Kerry N. L. Avery ${ }^{1}$ • \\ Eleanor Walsh $^{1} \cdot$ Michael Davis $^{1} \cdot$ Jenny L. Donovan $^{1} \cdot$ David E. Neal $^{5}$ • \\ Freddie C. Hamdy ${ }^{5} \cdot$ Jeff M. P. Holly ${ }^{2,3} \cdot$ J. Athene Lane ${ }^{1,2}$
}

Received: 7 October 2016/ Accepted: 17 June 2017/Published online: 23 June 2017

(C) The Author(s) 2017. This article is an open access publication

\begin{abstract}
Purpose The insulin-like growth factor (IGF) system is modifiable by diet and lifestyle, and has been linked to prostate cancer development and progression.

Methods We conducted a prospective cohort study of 621 men diagnosed with localized prostate cancer to investigate the associations of dietary and lifestyle changes with postdiagnosis circulating levels of IGF-I and IGFBP-3. We used analysis of covariance to estimate the associations, controlling for baseline IGF-I or IGFBP-3, respectively. Results Mean IGF-I levels were 6.5\% (95\% CI -12.8 , $-0.3 \%, p=0.04)$ lower in men who decreased their
\end{abstract}

Electronic supplementary material The online version of this article (doi:10.1007/s10552-017-0910-2) contains supplementary material, which is available to authorized users.

Vanessa Er, Kalina Biernacka, Jeff M. P. Holly, and J. Athene Lane have contributed equally to this work.

Vanessa Er

Vanessa.Er@bristol.ac.uk

1 School of Social and Community Medicine, University of Bristol, Canynge Hall, 39, Whatley Road, Bristol BS8 2PS, UK

2 National Institute for Health Research (NIHR) Bristol Nutrition Biomedical Research Unit, Level 3, University Hospitals Bristol Education \& Research Centre, Upper Maudlin Street, Bristol BS2 8AE, UK

3 IGFs and Metabolic Endocrinology Group, School of Clinical Sciences, University of Bristol, Learning and Research Building, Southmead Hospital, Bristol BS10 5NB, UK

4 Medical Research Council Integrative Epidemiology Unit, Oakfield House, Oakfield Grove, Bristol BS8 2BN, UK

5 Nuffield Department of Surgical Sciences, University of Oxford, John Radcliffe Hospital, Oxford OX3 9DU, UK protein intake after diagnosis compared to men who did not change. Men who changed their fruit and vegetable intake had lower IGF-I levels compared to non-changers [Decreased intake: $-10.1 \%, 95 \% \mathrm{CI}-18.4,-1.8 \%, p=0.02$; Increased intake: $-12.0 \%, 95 \%$ CI $-18.4,-1.8 \%$, $p=0.002]$. IGFBP-3 was $14.6 \%$ (95\% CI $-24.5,-4.8 \%$, $p=0.004)$ lower in men who achieved a healthy body mass index after diagnosis. Men who became inactive had 9.5\% higher average IGF-I levels (95\% CI 0.1, 18.9\%, $p=0.05$ ).

Conclusions Decreased protein intake and body mass index, and increased physical activity and fruit and vegetable intake, following a prostate cancer diagnosis were associated with reduced post-diagnosis serum IGF-I and IGFBP-3. Counterintuitively, reduced fruit and vegetable intake was also associated with reduced IGF-I, but with weak statistical support, possibly implicating chance. If confirmed in other studies, our findings may inform potential lifestyle interventions in prostate cancer. ProtecT was registered at International Standard Randomised Controlled Trial Registry, http://isrctn.org as ISRCTN20141297.

Keywords Prostatic neoplasms · Diet · Lifestyle · Insulinlike growth factors $\cdot$ Post-diagnosis

\section{Introduction}

The insulin-like growth factor (IGF) system has been implicated in the etiology and progression of various cancers, including prostate cancer [1-3]. Specifically, IGF-I is associated with increased risk of prostate cancer and higher risk of prostate cancer-specific mortality in men with advanced cancer $[2,3]$. It is a potent mitogen that promotes 
cell proliferation, metabolism and differentiation, and inhibits apoptosis [1]. About $90 \%$ of circulating IGF-I is bound to IGF binding protein-3 (IGFBP-3) [1], which regulates the bioavailability of IGF-I and suppresses its effects by inhibiting IGF-I binding to IGF cell-surface receptors. However, epidemiological evidence on IGFBP3's relationship with prostate cancer is mixed [2].

Circulating IGF levels are nutritionally regulated and may mediate the observed effects of diet on prostate cancer, including lycopene-rich foods, plant foods, calcium, and dairy products $[4,5]$. It is well established that IGF-I is elevated by protein and energy intake in malnourished individuals [6]. Dairy and calcium intakes are positively and consistently associated with IGF-I in epidemiological studies [7, 8], with randomized clinical trials showing increased IGF-I levels with higher milk intake [9, 10]. Conversely, lycopene-rich foods [11] and plant foods $[12,13]$ have been inversely linked to IGF-I. Associations of the IGF system with smoking, alcohol, and physical activity are uncertain $[1,12,14-16]$, while several studies have reported an inverted U-shaped relationship between body mass index (BMI) and IGF-I [17, 18].

As far as we know, no study has examined the longitudinal association of dietary and lifestyle changes with circulating IGF levels after a prostate cancer diagnosis. Most studies have been cross-sectional and involved cancer-free populations [7, 8, 12, 19]. One study investigated the 8-year associations of IGF peptides with lifestyle factors, but in young men who were cancer-free [15]. Here we investigate the association of changes in dietary intake or adherence to dietary and lifestyle recommendations with post-diagnosis circulating levels of IGF-I and IGFBP-3 in men diagnosed with prostate cancer in the Prostate testing for cancer and Treatment (ProtecT) randomized trial [20].

\section{Materials and methods}

\section{Study population}

ProtecT is a population-based randomized controlled trial investigating the effectiveness of treatments for PSA-detected localized prostate cancer [20]. Between 2001 and 2009, 228,966 men aged 50-69 years registered at general practices in nine UK cities were invited to attend a prostate check clinic. Over 82,000 men had a prostate-specific antigen (PSA) test, and consent was sought from men to provide additional blood samples for research purposes. They were also given a diet, health, and lifestyle (DHL) questionnaire to complete before receipt of their PSA results. Men with raised PSA $(\geq 3$ and $<20 \mathrm{ng} / \mathrm{mL}$; $n=8,566)$ were invited for repeated PSA test and a 10 core-transrectal ultrasound-guided biopsy. Tumors were assigned a Gleason score and cancers were staged using the tumor node metastasis (TNM) system.

Of the 7,414 men who underwent biopsy, 6,181 were given a DHL questionnaire at the prostate check clinic and 5,055 returned it (Fig. 1). Overall, 1,872 men were diagnosed with localized prostate cancer (T1-T2, NX, M0), of whom 1,518 were sent a follow-up DHL questionnaire between 2007 and 2010 with a mean follow-up time of 17 months. Blood samples were also collected at annual follow-up appointments from men who provided consent. We excluded men who did not return follow-up DHL questionnaires $(n=238)$, did not have baseline serum IGF-I or IGFBP-3 measurement $(n=169)$, or did not have blood collected within \pm 6 months of the follow-up DHL questionnaire return date $(n=455)$. One man had a markedly raised IGF-I $(617.0 \mathrm{ng} / \mathrm{mL})$ and IGFBP-3 $(8347.0 \mathrm{ng} / \mathrm{mL})$ and was excluded. We also excluded men who left the DHL questionnaires blank $(n=11)$, or reported total energy intake $<800$ or $>4000 \mathrm{kcal} /$ day $(n=25)$ [21]. This resulted in 619 men and 607 men for the IGF-I and IGFBP-3 analyses, respectively. Study participants gave informed consent for the use of their data for research purposes. The Trent Multicentre Research Ethics Committee approved the ProtecT trial and the associated ProMPT study.

\section{Data collection}

Trained nurses measured men's weight at the prostate check clinic according to a standard protocol. If unavailable, self-reported weight was used $(n=44)$. Weight was self-reported only at follow-up. Height was self-reported at baseline and follow-up. BMI was derived as weight over height squared $\left(\mathrm{kg} / \mathrm{m}^{2}\right)$. Godin's Leisure Time Physical Activity questionnaire was used to assess physical activity [22]. Physical activity was computed as number of times per week of moderate and strenuous exercise. Alcohol intake was estimated based on the number of units of spirits, wine, or beer consumed and the amount of alcohol (g) per drink. For smoking, we categorized men as never, former, and current smokers.

\section{Dietary questionnaire}

Dietary intake in the past 12 months was assessed using a validated 114 item-food frequency questionnaire (FFQ) adapted from the UK arm of the EPIC study [23]. Men reported frequency of intake for each food item across nine mutually exclusive categories, ranging from "never or less than once per month" to "six or more times per day." The assignment of portion size in grams for each food item was based on UK food portion sizes [24], food weights derived 
Fig. 1 Flow diagram of participants included in analysis. $P S A$ prostate-specific antigen ( $\geq 3.0$ and $<20.0 \mathrm{ng} /$ $\mathrm{mL}$ ). $D H L$ diet, health, and lifestyle, HGPIN high-grade prostatic intraepithelial neoplasia, ASAP atypical small acinar proliferation

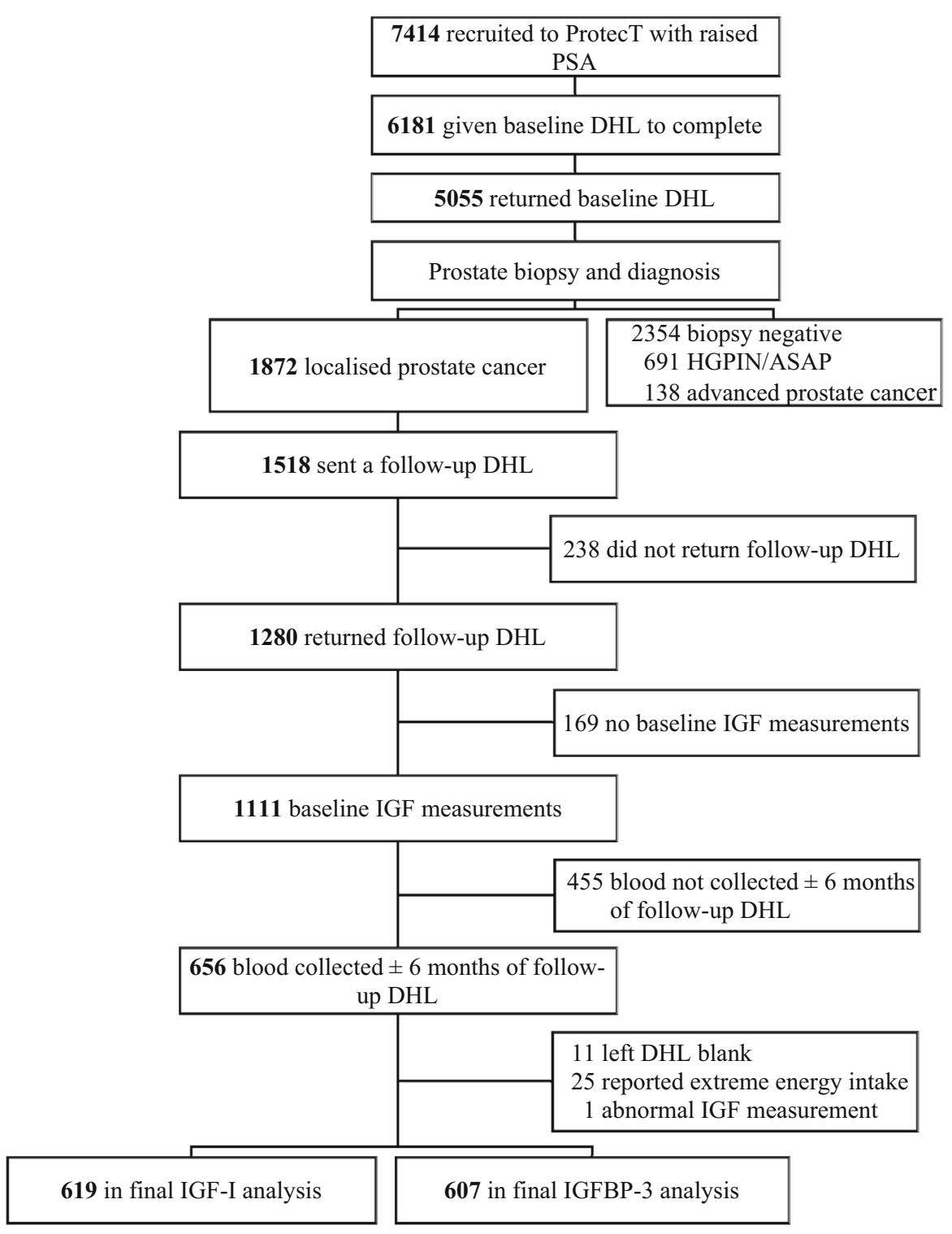

from a 7-day diet diary from a sub-sample of participants in ProtecT, and data from the Carnegie survey of diet and health [25]. Food intake was computed as the product of frequency of intake and portion size. Nutrient intake was derived by multiplying the frequency of intake by the nutrient content per portion of food, using nutrient values from the composition tables of McCance and Widdowson, and its supplements [26]. Refer to Supplementary Material 1 for definition of dairy products, fruits and vegetables, and foods rich in lycopene.

Dietary exposures were selected a priori based on their association with circulating IGFs or prostate cancer risk from the published literature and the World Cancer Research Fund and the American Institute for Cancer Research (WCRF/AICR) second expert report [4]. They include total energy intake, protein, dairy protein, dairy products, calcium, foods rich in lycopene, non-starch polysaccharide (NSP), and fruits and vegetables. Lifestyle exposures of interest were BMI, physical activity, alcohol intake and smoking status.

Since there were no recommended absolute intakes for total energy, total protein, dairy protein, and dairy products, we divided men into tertiles of baseline intake: low, medium, and high (Table 2), and categorized follow-up intake using the same cut-offs. We grouped men into three 'change' categories: no/minimal change (i.e., same category at baseline and follow-up assessments), decreased intake (high to low; or high to medium; or medium to low), and increased intake (low to medium; low to high; or medium to high). Where dietary or lifestyle public health recommendations were available, we categorized men into two categories based on their level of adherence (adherent 
vs. non-adherent) (Table 2). The cut-off criteria were derived from the WCRF/AICR second expert report for calcium, BMI, physical activity, and alcohol [4], and the Health Professionals Study for tomato and tomato products [27]. Cut-offs for non-starch polysaccharides [28] and fruits and vegetables [29] concur with UK dietary guidelines. We grouped men into four categories: non-adherent (NAd, i.e., non-adherent before and after diagnosis), nonadherent to adherent (NAd $\rightarrow \mathrm{Ad}$, i.e., men who became more 'healthy' after diagnosis), adherent to non-adherent $(\mathrm{Ad} \rightarrow \mathrm{NAd}$, i.e., men who became less 'healthy' after diagnosis), and adherent (Ad, i.e., adherent before and after diagnosis).

\section{Blood collection and IGF assays}

Non-fasted blood samples were drawn from men at recruitment (pre-diagnosis) between 2003 and 2008, and at annual follow-up appointments between 2007 and 2010. The samples were left to stand at room temperature and then centrifuged at approximately for $20 \mathrm{~min}$ to extract serum. They were kept at $5{ }^{\circ} \mathrm{C}$ during transportation to a laboratory, where they were aliquoted for storage at $-80{ }^{\circ} \mathrm{C}$ within $36 \mathrm{~h}$ of collection. Baseline and follow-up IGF-I and IGFBP-3 assays were carried out in JMPH's laboratory by staff blinded to dietary and lifestyle data using an in-house radio-immunoassay [30, 31], which measures total IGF-I and IGFBP-3, including all forms that have undergone minor fragmentation. Measurements were performed in triplicates and an average was computed for analyses.

Baseline serum samples were assayed between 2007 and 2010 to investigate the associations of IGFs and IGFBPs with prostate cancer risk in a case-control study nested within ProtecT [32]. Mean intra-assay coefficients of variation for baseline IGF-I and IGFBP-3 were 7.4 and $8.9 \%$, and mean inter-assay coefficients of variation were 11.3 and $12.5 \%$. All follow-up serum samples were assayed in 2014. Mean intra-assay coefficients of variation for follow-up IGF-I and IGFBP-3 were 7.6 and $6.8 \%$, and mean inter-assay coefficients of variation were 10.0 and $10.5 \%$.

\section{Statistical analysis}

Serum IGF-I and IGFBP-3 were approximately normally distributed. We used analysis of covariance (ANCOVA) to estimate associations of dietary and lifestyle changes with post-diagnosis IGF-I and IGFBP-3 separately (see Supplementary Material 1) [33,34]. All models were adjusted for baseline IGF values, baseline dietary, or lifestyle exposure of interest, baseline age, and follow-up time; for dietary exposures, the models were also adjusted for the difference in baseline and follow-up total energy intake (kcal/day) (Model 1 in Tables 3, 4, 5).

We compared the basic ANCOVA models with the models additionally adjusted for the following confounding factors identified a priori: height $(\mathrm{m})$, self-reported diabetes, occupational class, prostate cancer treatment received, and cancer grade. For the purpose of this analysis, tumors with Gleason score of $\leq 6$ were defined as low, and $\geq 7$ as high, grade. For dietary exposures, we also assessed potential confounding by baseline smoking status, dietary supplement intake, change in BMI, physical activity, and alcohol intake. However, most of these additional variables did not confound any of the observed associations, and only treatment received and cancer grade were added (in addition to the variables listed above in Model 1) to the fully adjusted regression models (Model 2 in Tables 3, 4, 5). Estimates from the fully adjusted regression models were presented as mean percentage difference of follow-up IGF-I or IGFBP-3, and are used to predict mean post-diagnosis IGF-I or IGFBP-3 levels for each category of preto post-diagnosis change in dietary or lifestyle behaviors. We estimated the Bonferroni correction for multiple testing based on the 24 tests carried out. All statistical analyses were performed using Stata v12.1 (StataCorp, College Station, TX USA).

\section{Results}

Our study population was predominantly White with an average age of 62 years, and a mean BMI of $27.1 \mathrm{~kg} / \mathrm{m}^{2}$ at recruitment (Table 1). The mean IGF-I and IGFBP-3 levels were $22.0 \mathrm{nmol} / \mathrm{mL}$ (standard deviation $(\mathrm{SD}): 7.1 \mathrm{nmol} /$ $\mathrm{mL}$ ) and $160.2 \mathrm{nmol} / \mathrm{mL}$ (SD: $34.5 \mathrm{nmol} / \mathrm{mL}$ ), respectively. The majority of the men were diagnosed with low grade cancer $(72.7 \%)$. Only a small proportion of men had a family history of prostate cancer $(8.7 \%)$ or had diabetes $(5.3 \%)$, and $52.3 \%$ of the men in the study reported taking dietary supplements.

Table 2 shows the cut-off criteria for categorizing dietary intake and adherence to dietary and lifestyle recommendations pre- and post-diagnosis, along with the proportion of men in each category. Intake of total energy, non-starch polysaccharide, and fruits and vegetables remained largely the same before and after diagnosis. There was a decrease in protein and dairy product intake postdiagnosis: the proportion of men who had high protein intake decreased by $3.9 \%$, and there were $4.5 \%$ fewer men with a high intake of dairy products. The reduction in protein intake may in part be due to a smaller contribution of dairy-derived protein $(4.9 \%$ decrease in high intake of dairy protein post-diagnosis). Conversely, men increased their consumption of foods rich in lycopene following a 
Table 1 Baseline characteristics of participants

\begin{tabular}{|c|c|c|}
\hline Characteristics & $n=619$ & $\begin{array}{l}\text { Mean (SD) or } \\
\%\end{array}$ \\
\hline Age at recruitment (years) & 619 & $62.0(4.9)$ \\
\hline Height (m) & 610 & $1.76(0.06)$ \\
\hline Weight (kg) & 618 & $84.2(12.0)$ \\
\hline BMI $\left(\mathrm{kg} / \mathrm{m}^{2}\right)$ & 610 & $27.1(3.5)$ \\
\hline Time since diagnosis (months) & 619 & $17(9)$ \\
\hline \multicolumn{3}{|c|}{ Serum IGF concentrations $(\mathrm{nmol} / \mathrm{mL})$} \\
\hline IGF-I & 619 & $22.0(7.1)$ \\
\hline IGFBP-3 & 607 & $160.2(34.5)$ \\
\hline \multicolumn{3}{|l|}{ Ethnicity } \\
\hline White & 607 & 98.1 \\
\hline Others & 5 & 0.8 \\
\hline Unknown & 7 & 1.1 \\
\hline \multicolumn{3}{|l|}{ Occupational class } \\
\hline Managerial & 273 & 44.1 \\
\hline Intermediate & 99 & 16.0 \\
\hline Working & 238 & 38.5 \\
\hline Unknown & 9 & 1.4 \\
\hline \multicolumn{3}{|l|}{ Family history of prostate cancer } \\
\hline Yes & 54 & 8.7 \\
\hline No & 512 & 82.7 \\
\hline Do not know & 41 & 6.6 \\
\hline Unknown & 12 & 2.0 \\
\hline \multicolumn{3}{|l|}{ Diabetes } \\
\hline Yes & 33 & 5.3 \\
\hline No & 541 & 87.4 \\
\hline Unknown & 45 & 7.3 \\
\hline \multicolumn{3}{|l|}{ PSA level } \\
\hline$<10.0 \mathrm{ng} / \mathrm{mL}$ & 549 & 88.7 \\
\hline $10.0-20.0 \mathrm{ng} / \mathrm{mL}$ & 70 & 11.3 \\
\hline \multicolumn{3}{|l|}{ Treatment } \\
\hline Active monitoring & 275 & 44.4 \\
\hline Prostatectomy & 176 & 38.4 \\
\hline Radiotherapy & 167 & 27.0 \\
\hline Other & 1 & 0.2 \\
\hline \multicolumn{3}{|l|}{ Gleason grade $^{\mathrm{a}}$} \\
\hline Low $(2-6)$ & 450 & 72.7 \\
\hline High (7-10) & 169 & 27.3 \\
\hline \multicolumn{3}{|l|}{ Vitamin/dietary supplement intake } \\
\hline Yes & 324 & 52.3 \\
\hline No & 282 & 45.6 \\
\hline Unknown & 13 & 2.1 \\
\hline
\end{tabular}

${ }^{\text {a }}$ Gleason scores of 2, 3, and 4 were acceptable when the ProtecT trial was conducted as it was before the 2005 International Society of Urological Pathology [44]

diagnosis. There was a $2.5 \%$ increase in men who had over 10 servings of tomatoes and tomato products per week; adherence to the physical activity recommendation also increased by about $3 \%$ following a diagnosis. There was a $2.2 \%$ fall in the proportion of overweight or obese men. Some men (2\%) quit smoking following a prostate cancer diagnosis, but alcohol consumption largely remained unchanged.

Table 3 presents the associations of changes in total energy, total protein, dairy protein, and dairy product intake with IGF-I and IGFBP-3 levels following a prostate cancer diagnosis. Average IGF-I levels were 6.5\% (95\% CI $-12.8,-0.3 \%, p=0.04)$ lower in men who decreased their protein intake compared to men who did not change (minimal change). None of the dietary exposures we investigated were associated with post-diagnosis IGFBP-3.

Table 4 shows the associations of changes in adherence to dietary recommendations with IGF-I and IGFBP-3 levels following a prostate cancer diagnosis. Men who consumed $<5$ portions/day of fruits and vegetables before diagnosis, but increased to $\geq 5$ after their diagnosis (NAd $\rightarrow$ Ad), had post-diagnosis IGF-I levels that were on average $12.0 \%$ (95\% CI $-20.1,-3.9 \% ; p=0.002$ ) lower than those who did not change and consumed $<5$ portions/day (NAd). Average post-diagnosis IGF-I levels were also lower among men who had $\geq 5$ portions/day of fruits and vegetables before diagnosis but decreased to $<5$ after diagnosis (Ad $\rightarrow$ NAd: $-10.1 \%, 95 \%$ CI $-18.4,-1.8 \%, p=0.02$ ). Adherence to the fruits and vegetables recommendation before and after diagnosis (Ad) was also linked to postdiagnosis IGF-I levels that were $8.8 \%$ lower on average (95\% CI $-15.8,-1.8, p=0.01)$. Conversely, post-diagnosis serum IGFBP-3 levels were not associated with changes in adherence to recommendations on calcium, tomatoes and tomato products, non-starch polysaccharide, or fruits and vegetables.

Table 5 presents the associations of lifestyle changes with IGF-I and IGFBP-3 levels following a prostate cancer diagnosis. There was weak evidence that men who were active before diagnosis but became inactive after their diagnosis $(\mathrm{Ad} \rightarrow \mathrm{NAd})$ had post-diagnosis IGF-I levels that were $9.5 \%$ higher on average $(95 \%$ CI $0.1,18.9 \%$, $p=0.05)$ than men who were inactive and did not change. Average post-diagnosis IGFBP-3 levels were 14.6\% (95\% CI $-24.5,-4.8 \% ; p=0.004)$ lower in men who were overweight before diagnosis and acquired a healthy BMI after diagnosis (NAd $\rightarrow$ Ad). A similar difference was observed for men who had healthy BMI before and after diagnosis (Ad vs NAd: $-9.2 \%, 95 \%$ CI $-16.8,-1.6 \%$; $p=0.02$ ). Post-diagnosis IGFBP-3 levels were $10.7 \%$ (95\% CI $-19.3,-2.1 \%, p=0.02$ ) lower in men who adhered to the physical activity recommendation before and after diagnosis compared to men who were non-adherent and did not change. Finally, the association between increased fruit and vegetable intake and IGF-I level post- 
Table 2 Dietary intake and adherence to public health recommendations before and after diagnosis

\begin{tabular}{|c|c|c|c|c|c|c|c|}
\hline & \multirow[t]{2}{*}{ Cut-off points } & \multirow[t]{2}{*}{ Intake/adherence $^{\mathrm{a}}$} & \multicolumn{2}{|c|}{$\begin{array}{l}\text { Pre-diagnosis } \\
(n=619)\end{array}$} & \multicolumn{2}{|c|}{$\begin{array}{l}\text { Post-diagnosis } \\
(n=619)\end{array}$} & \multirow[t]{2}{*}{$\overline{p-\text { value }^{f}}$} \\
\hline & & & $n$ & $\%$ & $n$ & $\%$ & \\
\hline \multirow[t]{3}{*}{ Total energy } & 800.0 to $<1995.3 \mathrm{kcal} /$ day & Low & 207 & 33.4 & 210 & 33.9 & \\
\hline & $\geq 1995.3$ to $<2529.8 \mathrm{kcal} /$ day & Medium & 206 & 33.3 & 208 & 33.6 & \\
\hline & $\geq 2529.8$ to $4000.0 \mathrm{kcal} /$ day & High & 206 & 33.3 & 201 & 32.5 & 0.78 \\
\hline \multirow[t]{3}{*}{ Total protein } & $<76.3$ g/day & Low & 207 & 33.4 & 215 & 34.7 & \\
\hline & $\geq 76.3$ to $<97.9 \mathrm{~g} /$ day & Medium & 206 & 33.3 & 222 & 35.9 & \\
\hline & $\geq 97.9$ g/day & High & 206 & 33.3 & 182 & 29.4 & 0.27 \\
\hline \multirow[t]{3}{*}{ Dairy protein } & $<12.1 \mathrm{~g} /$ day & Low & 207 & 33.4 & 240 & 38.8 & \\
\hline & $\geq 12.1 \mathrm{~g}$ to $<18.6 \mathrm{~g} /$ day & Medium & 206 & 33.3 & 203 & 32.8 & \\
\hline & $\geq 18.6 \mathrm{~g} /$ day & High & 206 & 33.3 & 176 & 28.4 & 0.03 \\
\hline \multirow[t]{3}{*}{ Dairy products ${ }^{\mathrm{b}}$} & $<292.7$ g/day & Low & 207 & 33.4 & 233 & 37.6 & \\
\hline & $\geq 293.7$ to $<439.4 \mathrm{~g} /$ day & Medium & 207 & 33.4 & 209 & 33.8 & \\
\hline & $\geq 439.4$ g/day & High & 205 & 33.1 & 177 & 28.6 & 0.06 \\
\hline \multirow[t]{2}{*}{ Calcium } & $\geq 700$ to $<1500 \mathrm{mg} /$ day & Ad & 481 & 77.7 & 464 & 75.0 & \\
\hline & $<700$ or $\geq 1500 \mathrm{mg} /$ day & Non-Ad & 138 & 22.3 & 155 & 25.0 & 0.18 \\
\hline \multirow[t]{2}{*}{ Tomato products } & $>10$ servings/week & Ad & 56 & 9.0 & 71 & 11.5 & \\
\hline & $\leq 10$ servings/week & Non-Ad & 563 & 91.0 & 548 & 88.5 & 0.09 \\
\hline \multirow[t]{2}{*}{ Non-starch polysaccharides } & $\geq 18 \mathrm{~g} /$ day & Ad & 380 & 61.4 & 385 & 62.2 & \\
\hline & $<18$ g/day & Non-Ad & 239 & 38.6 & 234 & 37.8 & 0.70 \\
\hline \multirow[t]{2}{*}{ Fruits and vegetables ${ }^{\mathrm{d}, \mathrm{e}}$} & $\geq 5$ portions/day & Ad & 355 & 57.4 & 353 & 57.0 & \\
\hline & $<5$ portions/day & Non-Ad & 264 & 42.6 & 266 & 43.0 & 0.87 \\
\hline \multirow[t]{2}{*}{ Body mass index ${ }^{e}$} & $\geq 18.5$ to $<25 \mathrm{~kg} / \mathrm{m}^{2}$ & $\mathrm{Ad}$ & 167 & 28.5 & 180 & 30.7 & \\
\hline & $\geq 25 \mathrm{~kg} / \mathrm{m}^{2}$ & Non-Ad & 419 & 71.5 & 406 & 69.3 & 0.09 \\
\hline \multirow[t]{2}{*}{ Physical activity } & $\geq 7$ times/week & $\mathrm{Ad}$ & 165 & 29.1 & 183 & 32.3 & \\
\hline & $<7$ times/week & Non-Ad & 402 & 70.9 & 384 & 67.7 & 0.16 \\
\hline \multirow[t]{2}{*}{ Alcohol $^{\mathrm{e}}$} & $\leq 20 \mathrm{~g} /$ day & $\mathrm{Ad}$ & 351 & 57.5 & 353 & 57.9 & \\
\hline & $>20$ g/day & Non-Ad & 259 & 42.5 & 257 & 42.1 & 0.86 \\
\hline \multirow[t]{3}{*}{ Smoking status ${ }^{\mathrm{e}}$} & Never & $\mathrm{n} / \mathrm{a}$ & 256 & 42.1 & 255 & 41.9 & \\
\hline & Former & $\mathrm{n} / \mathrm{a}$ & 295 & 48.4 & 307 & 50.4 & \\
\hline & Current & $\mathrm{n} / \mathrm{a}$ & 58 & 9.5 & 47 & 7.7 & 0.09 \\
\hline \multicolumn{8}{|c|}{ Ad Adherence, Non-Ad Non-adherence } \\
\hline \multicolumn{8}{|c|}{ For definition of dairy products, tomato products, and physical activity, refer to Methods and Supplementary Material 1} \\
\hline \multicolumn{8}{|l|}{ c Includes fresh tomatoes } \\
\hline \multicolumn{8}{|c|}{ d 1 portion equivalent to $400 \mathrm{~g}$} \\
\hline \multicolumn{8}{|c|}{ e Men with complete data only: BMI $(n=586)$, physical activity $(n=567)$, alcohol $(n=610)$, smoking status $(n=609)$} \\
\hline
\end{tabular}

diagnosis was the only finding robust to Bonferroni correction (i.e., $p=0.05 / 24 ; p=0.002$ ).

\section{Discussion}

To our knowledge, our study is the first to assess associations of changes in dietary and lifestyle behaviors with circulating IGF-I and IGFBP-3 levels following a diagnosis of prostate cancer. We observed associations of post-diagnosis serum IGF-I and IGFBP-3 levels with changes in protein intake and changes in adherence to recommendations on fruits and vegetables, BMI, and physical activity following a prostate cancer diagnosis.

Unlike most studies [35-37], there were negligible changes in smoking, non-starch polysaccharide, and fruit and vegetable intake in our study population. Instead, there was a small reduction in the proportion of men in the high 
Table 3 Changes in dietary intake and follow-up IGF level, adjusted for baseline IGF

\begin{tabular}{|c|c|c|c|c|c|c|}
\hline & \multirow[t]{2}{*}{$n$} & \multirow[t]{2}{*}{$\begin{array}{l}\text { Mean change } \\
\text { in intake }\end{array}$} & \multirow[t]{2}{*}{$\begin{array}{l}\text { Mean follow-up } \\
\text { intake }\end{array}$} & \multirow[t]{2}{*}{$\begin{array}{l}\text { Mean follow-up } \\
\text { IGF }^{\mathrm{a}}\end{array}$} & \multicolumn{2}{|c|}{$\begin{array}{l}\text { Difference }(95 \% \mathrm{CI}) \text { in mean follow-up serum IGF } \\
\text { concentration }(\%)\end{array}$} \\
\hline & & & & & Model $1^{\mathrm{b}}$ & Model $2^{\mathrm{c}}$ \\
\hline \multicolumn{7}{|c|}{ IGF-I $(n=619)$} \\
\hline \multicolumn{7}{|c|}{ Total energy (kcal/day) } \\
\hline No change & 309 & -13.5 & 2294.8 & 20.3 & Ref & Ref \\
\hline Decreased & 156 & -649.3 & 1955.1 & 20.3 & $-1.2(-7.0,4.6)$ & $-1.7(-7.5,4.1)$ \\
\hline Increased & 154 & 661.3 & 2602.7 & 20.8 & $4.3(-1.5,10.2)$ & $4.3(-1.6,10.1)$ \\
\hline \multicolumn{7}{|c|}{ Total protein (g/day) } \\
\hline No change & 325 & 0.0 & 86.6 & 20.8 & Ref & Ref \\
\hline Decreased & 158 & -26.6 & 75.8 & 19.5 & $-6.5(-12.9,-0.2)$ & $-6.5(-12.8,-0.3)^{*}$ \\
\hline Increased & 136 & 25.4 & 102.2 & 20.5 & $3.7(-2.9,10.2)$ & $4.5(-2.0,11.1)$ \\
\hline \multicolumn{7}{|c|}{ Dairy protein (g/day) } \\
\hline No change & 351 & -0.3 & 15.5 & 20.2 & Ref & Ref \\
\hline Decreased & 160 & -7.4 & 11.9 & 21.0 & $3.3(-2.3,9.0)$ & $4.1(-1.5,9.7)$ \\
\hline Increased & 108 & 7.0 & 19.1 & 20.1 & $-0.2(-6.7,6.4)$ & $0.2(-6.3,6.7)$ \\
\hline \multicolumn{7}{|c|}{ Dairy products $^{\mathrm{d}}$ (g/day) } \\
\hline No change & 372 & -10.2 & 360.1 & 20.5 & Ref & Ref \\
\hline Decreased & 148 & -181.2 & 274.7 & 19.8 & $-2.3(-8.1,3.4)$ & $-2.2(-7.8,3.5)$ \\
\hline Increased & 99 & 179.3 & 462.3 & 20.7 & $2.5(-4.2,9.1)$ & $2.0(-4.6,8.6)$ \\
\hline \multicolumn{7}{|c|}{ IGFBP-3 $(n=607)$} \\
\hline \multicolumn{7}{|c|}{ Total energy (kcal/day) } \\
\hline No change & 301 & -10.0 & 2304.7 & 130.6 & Ref & Ref \\
\hline Decreased & 154 & -648.4 & 1952.4 & 133.9 & $2.7(-2.7,8.2)$ & $2.8(-2.7,8.2)$ \\
\hline Increased & 152 & 660.8 & 2601.1 & 130.3 & $0.4(-5.1,5.9)$ & $0.6(-5.0,6.1)$ \\
\hline \multicolumn{7}{|c|}{ Total protein (g/day) } \\
\hline No change & 320 & 0.2 & 86.8 & 133.0 & Ref & Ref \\
\hline Decreased & 157 & -26.4 & 75.9 & 129.4 & $-2.2(-8.2,3.7)$ & $-2.3(-8.3,3.7)$ \\
\hline Increased & 134 & 25.6 & 102.1 & 129.7 & $-2.2(-8.4,4.0)$ & $-2.0(-8.3,4.2)$ \\
\hline \multicolumn{7}{|c|}{ Dairy protein (g/day) } \\
\hline No change & 344 & -0.3 & 15.4 & 130.1 & Ref & Ref \\
\hline Decreased & 156 & -7.4 & 12.0 & 131.5 & $1.8(-3.6,7.1)$ & $2.0(-3.3,7.4)$ \\
\hline Increased & 107 & 7.0 & 19.1 & 135.3 & $3.1(-3.0,9.2)$ & $3.0(-3.1,9.2)$ \\
\hline \multicolumn{7}{|c|}{ Dairy products $^{\mathrm{d}}$ (g/day) } \\
\hline No change & 367 & -11.0 & 360.7 & 130.7 & Ref & Ref \\
\hline Decreased & 143 & -183.8 & 274.3 & 128.3 & $-0.4(-5.8,5.0)$ & $-0.3(-5.7,5.1)$ \\
\hline Increased & 97 & 180.0 & 461.9 & 138.4 & $5.3(-0.9,11.5)$ & $5.2(-1.1,11.4)$ \\
\hline
\end{tabular}

${ }^{a}$ Mean predicted from fully adjusted regression model $(\mathrm{nmol} / \mathrm{mL})$

b Adjusted for baseline age, baseline IGF, baseline dietary intake, follow-up time point, and changes in energy intake (except that for total energy)

${ }^{c}$ Further adjusted for treatment received and cancer grade

${ }^{\mathrm{d}}$ For definition of dairy products, refer to Supplementary Material 1. $* p=0.04$

dairy intake category (median decrease of 0.5 serving/day in men who decreased intake) and a slight increase in the proportion of men who consumed $>10$ servings/week of tomatoes and tomato products (median increase of 8.0 servings/week in men who increased intake). This could be due to a heightened awareness of the link between these dietary factors and prostate cancer risk since the publication of the WCRF/AICR second expert report [4]. There was also a marginal increase in the proportion of men who adhered to the physical activity or healthy weight recommendation post-diagnosis (mean increase of 5.5 times/ week of moderate to strenuous physical activity, and mean 
Table 4 Changes in adherence to dietary recommendations and follow-up IGF level, adjusted for baseline IGF

\begin{tabular}{|c|c|c|c|c|c|c|}
\hline & \multirow[t]{2}{*}{$n$} & \multirow[t]{2}{*}{$\begin{array}{l}\text { Mean change } \\
\text { in intake }\end{array}$} & \multirow[t]{2}{*}{$\begin{array}{l}\text { Mean follow-up } \\
\text { intake }\end{array}$} & \multirow[t]{2}{*}{$\begin{array}{l}\text { Mean follow-up } \\
\text { IGF }^{\mathrm{a}}\end{array}$} & \multicolumn{2}{|c|}{$\begin{array}{l}\text { Difference }(95 \% \mathrm{CI}) \text { in mean follow-up serum } \\
\text { IGF concentration }(\%)\end{array}$} \\
\hline & & & & & Model $1^{\mathrm{b}}$ & Model $2^{\mathrm{c}}$ \\
\hline \multicolumn{7}{|l|}{ IGF-I $(\mathrm{n}=619)$} \\
\hline \multicolumn{7}{|l|}{ Calcium (mg/day) } \\
\hline Non-adherent & 66 & 19.5 & 1038.4 & 20.0 & Ref & Ref \\
\hline $\mathrm{Ad} \rightarrow \mathrm{NAd}$ & 89 & -95.5 & 944.9 & 20.7 & $0.1(-9.4,9.5)$ & $-0.4(-9.8,8.9)$ \\
\hline $\mathrm{NAd} \rightarrow \mathrm{Ad}$ & 72 & -23.6 & 1049.9 & 19.8 & $-0.6(-10.5,9.2)$ & $-0.3(-10.0,9.5)$ \\
\hline Adherent & 392 & -19.3 & 1025.4 & 20.5 & $0.7(-7.0,8.4)$ & $0.5(-7.2,8.1)$ \\
\hline \multicolumn{7}{|c|}{ Tomato products ${ }^{\mathrm{d}, \mathrm{e}}$ (serving/week) } \\
\hline Non-adherent & 517 & 0 & 4.5 & 20.7 & Ref & Ref \\
\hline $\mathrm{Ad} \rightarrow \mathrm{NAd}$ & 31 & -9.5 & 6.0 & 18.5 & $-14.1(-28.4,0.1)$ & $-13.8(-27.9,0.3)$ \\
\hline $\mathrm{NAd} \rightarrow \mathrm{Ad}$ & 46 & 9.5 & 16.0 & 19.0 & $-6.3(-15.3,2.7)$ & $-5.3(-14.2,3.7)$ \\
\hline Adherent & 25 & -2.5 & 15.0 & 19.9 & $-3.7(-19.6,12.3)$ & $-6.2(-22.1,9.6)$ \\
\hline \multicolumn{7}{|l|}{ NSP (g/day) } \\
\hline Non-adherent & 153 & 0.2 & 13.7 & 21.1 & Ref & Ref \\
\hline $\mathrm{Ad} \rightarrow \mathrm{NAd}$ & 81 & -8.7 & 15.2 & 19.4 & $-4.9(-13.9,4.2)$ & $-4.6(-13.5,4.4)$ \\
\hline $\mathrm{NAd} \rightarrow \mathrm{Ad}$ & 86 & 8.4 & 23.0 & 19.4 & $-3.9(-12.3,4.5)$ & $-3.6(-11.9,4.8)$ \\
\hline Adherent & 399 & 0.3 & 27.1 & 20.6 & $-0.7(-8.8,7.5)$ & $-0.4(-8.5,7.6)$ \\
\hline \multicolumn{7}{|c|}{ Fruit and vegetables ${ }^{\mathrm{d}}$ (portion/day) } \\
\hline Non-adherent & 193 & 0 & 3.5 & 21.6 & Ref & Ref \\
\hline $\mathrm{Ad} \rightarrow \mathrm{NAd}$ & 73 & -2.5 & 4.0 & 20.2 & $-10.4(-18.9,-2.0)$ & $-10.1(-18.4,-1.8)^{*}$ \\
\hline $\mathrm{NAd} \rightarrow \mathrm{Ad}$ & 71 & 3.0 & 7.0 & 18.3 & $-12.9(-21.0,-4.7)$ & $-12.0(-20.1,-3.9) * * *$ \\
\hline Adherent & 282 & 0 & 8.0 & 20.2 & $-8.9(-15.9,-1.8)$ & $-8.8(-15.8,-1.8)^{* *}$ \\
\hline \multicolumn{7}{|c|}{ IGFBP-3 $(n=607)$} \\
\hline \multicolumn{7}{|l|}{ Calcium (mg/day) } \\
\hline Non-adherent & 64 & 22.5 & 1056.4 & 124.7 & Ref & Ref \\
\hline $\mathrm{Ad} \rightarrow \mathrm{NAd}$ & 86 & -97.8 & 943.8 & 132.6 & $3.7(-5.2,12.6)$ & $3.9(-5.0,12.9)$ \\
\hline $\mathrm{NAd} \rightarrow \mathrm{Ad}$ & 72 & -23.6 & 1049.9 & 126.7 & $1.3(-7.9,10.5)$ & $1.1(-8.1,10.4)$ \\
\hline Adherent & 385 & -18.6 & 1026.3 & 133.1 & $5.1(-2.2,12.3)$ & $5.0(-2.2,12.3)$ \\
\hline \multicolumn{7}{|c|}{ Tomato products ${ }^{\mathrm{d}, \mathrm{e}}$ (serving/week) } \\
\hline Non-adherent & 506 & 0 & 4.5 & 132.4 & Ref & Ref \\
\hline $\mathrm{Ad} \rightarrow \mathrm{NAd}$ & 31 & -9.5 & 6.0 & 137.9 & $2.0(-11.3,15.2)$ & $1.9(-11.4,15.2)$ \\
\hline $\mathrm{NAd} \rightarrow \mathrm{Ad}$ & 45 & 9.5 & 16.0 & 124.4 & $-5.3(-13.8,3.1)$ & $-5.2(-13.7,3.2)$ \\
\hline Adherent & 25 & -2.5 & 15.0 & 114.1 & $-12.5(-27.4,2.3)$ & $-13.5(-28.4,1.5)$ \\
\hline \multicolumn{7}{|l|}{ NSP (g/day) } \\
\hline Non-adherent & 151 & 0.2 & 13.7 & 134.2 & Ref & Ref \\
\hline $\mathrm{Ad} \rightarrow \mathrm{NAd}$ & 77 & -8.7 & 15.3 & 129.4 & $-0.6(-9.1,8.0)$ & $-0.7(-9.3,7.8)$ \\
\hline $\mathrm{NAd} \rightarrow \mathrm{Ad}$ & 85 & 8.3 & 22.9 & 128.2 & $-2.2(-10.0,5.6)$ & $-2.0(-9.9,5.9)$ \\
\hline Adherent & 294 & 0.3 & 27.1 & 131.3 & $0.0(-7.6,7.7)$ & $0.0(-7.6,7.7)$ \\
\hline \multicolumn{7}{|c|}{ Fruit and vegetables ${ }^{\mathrm{d}}$ (portion/day) } \\
\hline Non-adherent & 189 & 0 & 3.5 & 131.6 & Ref & Ref \\
\hline $\mathrm{Ad} \rightarrow \mathrm{NAd}$ & 71 & -2.5 & 4.0 & 136.2 & $3.9(-4.1,11.9)$ & $4.2(-3.8,12.2)$ \\
\hline $\mathrm{NAd} \rightarrow \mathrm{Ad}$ & 69 & 3.0 & 7.0 & 123.7 & $-2.7(-10.4,5.0)$ & $-2.3(-10.1,5.5)$ \\
\hline Adherent & 278 & 0 & 8.0 & 131.9 & $1.4(-5.2,8.0)$ & $1.4(-5.2,8.1)$ \\
\hline
\end{tabular}

${ }^{a}$ Mean predicted from fully adjusted regression model

b Adjusted for baseline age, baseline IGF, baseline dietary intake, follow-up time point, and changes in energy intake

${ }^{c}$ Further adjusted for treatment received and cancer grade

${ }^{\mathrm{d}}$ Rounded to the nearest 0.5 serving/week or portion/day

${ }^{\mathrm{e}}$ Includes fresh tomatoes. For definition of tomato products, refer to Supplementary Material 1. NSP non-starch polysaccharides

${ }^{*} p=0.02, * * p=0.01, * * * p=0.002$ 
Table 5 Changes in adherence to lifestyle recommendations and follow-up IGF level, adjusted for baseline IGF

\begin{tabular}{|c|c|c|c|c|c|c|}
\hline & \multirow[t]{2}{*}{$n$} & \multirow[t]{2}{*}{ Mean change } & \multirow[t]{2}{*}{$\begin{array}{l}\text { Mean at } \\
\text { follow-up }\end{array}$} & \multirow[t]{2}{*}{$\begin{array}{l}\text { Mean follow-up } \\
\text { IGF }^{\mathrm{a}}\end{array}$} & \multicolumn{2}{|c|}{$\begin{array}{l}\text { Difference }(95 \% \mathrm{CI}) \text { in mean follow-up serum IGF } \\
\text { concentration }(\%)^{\mathrm{b}}\end{array}$} \\
\hline & & & & & Model $1^{\mathrm{b}}$ & Model $2^{\mathrm{c}}$ \\
\hline \multicolumn{7}{|l|}{ IGF-I $(n=619)$} \\
\hline \multicolumn{7}{|l|}{$\mathrm{BMI}\left(\mathrm{kg} / \mathrm{m}^{2}\right)$} \\
\hline Non-adherent & 383 & -0.2 & 28.6 & 20.3 & Ref & Ref \\
\hline $\mathrm{Ad} \rightarrow \mathrm{NAd}$ & 23 & 1.4 & 25.7 & 21.7 & $3.1(-10.1,16.2)$ & $6.6(-6.6,19.8)$ \\
\hline $\mathrm{NAd} \rightarrow \mathrm{Ad}$ & 36 & -1.8 & 24.2 & 20.6 & $-1.3(-11.6,9.1)$ & $0.4(-9.9,10.6)$ \\
\hline Adherent & 144 & -0.1 & 22.9 & 20.1 & $-5.7(-13.7,2.3)$ & $-4.2(-12.1,3.8)$ \\
\hline \multicolumn{7}{|c|}{ Physical activity ${ }^{\mathrm{d}}$ (times/week) } \\
\hline Non-adherent & 321 & 0.5 & 2.5 & 20.5 & Ref & Ref \\
\hline $\mathrm{Ad} \rightarrow \mathrm{NAd}$ & 65 & -5.0 & 3.5 & 21.3 & $10.1(0.6,19.7)$ & $9.5(0.1,18.9)^{*}$ \\
\hline $\mathrm{NAd} \rightarrow \mathrm{Ad}$ & 83 & 5.5 & 8.5 & 21.2 & $3.8(-3.4,11.0)$ & $3.3(-3.9,10.4)$ \\
\hline Adherent & 100 & 0.5 & 10.5 & 19.6 & $3.7(-5.7,13.1)$ & $4.2(-5.1,13.5)$ \\
\hline \multicolumn{7}{|c|}{ Alcohol intake (g/day) } \\
\hline Non-adherent & 199 & 1.1 & 45.9 & 20.2 & Ref & Ref \\
\hline $\mathrm{Ad} \rightarrow \mathrm{NAd}$ & 58 & 15.6 & 29.1 & 19.7 & $0.4(-9.7,10.5)$ & $2.1(-7.9,12.1)$ \\
\hline $\mathrm{NAd} \rightarrow \mathrm{Ad}$ & 60 & -22.5 & 11.9 & 20.3 & $3.2(-5.5,11.8)$ & $5.8(-2.8,14.5)$ \\
\hline Adherent & 293 & -0.7 & 6.3 & 20.7 & $6.6(-1.7,14.9)$ & $8.0(-0.2,16.2)$ \\
\hline \multicolumn{7}{|l|}{ Smoking $^{\mathrm{d}}$} \\
\hline Never & 256 & $\mathrm{n} / \mathrm{a}$ & $\mathrm{n} / \mathrm{a}$ & 20.7 & Ref & Ref \\
\hline Former & 295 & $\mathrm{n} / \mathrm{a}$ & $\mathrm{n} / \mathrm{a}$ & 20.1 & $-1.1(-6.1,3.8)$ & $-1.1(-6.0,3.8)$ \\
\hline Current & 58 & $\mathrm{n} / \mathrm{a}$ & $\mathrm{n} / \mathrm{a}$ & 20.9 & $-0.2(-8.5,8.1)$ & $-0.2(-8.4,8.1)$ \\
\hline \multicolumn{7}{|c|}{ IGFBP-3 $(n=607)$} \\
\hline \multicolumn{7}{|c|}{ BMI $\left(\mathrm{kg} / \mathrm{m}^{2}\right)$} \\
\hline Non-adherent & 377 & -0.2 & 28.6 & 133.4 & Ref & Ref \\
\hline $\mathrm{Ad} \rightarrow \mathrm{NAd}$ & 22 & 1.4 & 25.6 & 131.4 & $-7.7(-20.2,4.8)$ & $-8.2(-21.0,4.6)$ \\
\hline $\mathrm{NAd} \rightarrow \mathrm{Ad}$ & 35 & -1.8 & 24.2 & 123.6 & $-14.9(-24.7,-5.1)$ & $-14.6(-24.5,-4.8) * * *$ \\
\hline Adherent & 140 & -0.1 & 23.0 & 126.1 & $-9.5(-17.0,-2.0)$ & $-9.2(-16.8,-1.6)^{* *}$ \\
\hline \multicolumn{7}{|c|}{ Physical activity ${ }^{\mathrm{d}}$ (times/week) } \\
\hline Non-adherent & 311 & 0 & 2.5 & 130.2 & Ref & Ref \\
\hline $\mathrm{Ad} \rightarrow \mathrm{NAd}$ & 64 & -5.0 & 3.5 & 143.5 & $3.5(-5.2,12.3)$ & $3.5(-5.2,12.3)$ \\
\hline $\mathrm{NAd} \rightarrow \mathrm{Ad}$ & 82 & 5.5 & 8.5 & 129.7 & $-2.4(-9.0,4.2)$ & $-2.6(-9.2,4.0)$ \\
\hline Adherent & 98 & 0.5 & 10.5 & 126.6 & $-10.7(-19.3,-2.1)$ & $-10.7(-19.3,-2.1)^{* *}$ \\
\hline \multicolumn{7}{|c|}{ Alcohol intake (g/day) } \\
\hline Non-adherent & 198 & 0.9 & 45.5 & 133.8 & Ref & Ref \\
\hline $\mathrm{Ad} \rightarrow \mathrm{NAd}$ & 57 & 15.8 & 29.2 & 134.8 & $2.3(-7.2,11.7)$ & $2.8(-6.7,12.2)$ \\
\hline $\mathrm{NAd} \rightarrow \mathrm{Ad}$ & 60 & -22.5 & 11.9 & 129.8 & $-1.1(-9.2,6.9)$ & $-0.4(-8.5,7.7)$ \\
\hline Adherent & 283 & -0.7 & 6.3 & 129.3 & $-2.2(-9.9,5.5)$ & $-2.0(-9.7,5.8)$ \\
\hline \multicolumn{7}{|l|}{ Smoking $^{\mathrm{e}}$} \\
\hline Never & 255 & $\mathrm{n} / \mathrm{a}$ & $\mathrm{n} / \mathrm{a}$ & 136.6 & Ref & Ref \\
\hline Former & 296 & $\mathrm{n} / \mathrm{a}$ & $\mathrm{n} / \mathrm{a}$ & 130.1 & $-0.5(-5.1,4.1)$ & $-0.5(-5.1,4.1)$ \\
\hline Current & 56 & $\mathrm{n} / \mathrm{a}$ & $\mathrm{n} / \mathrm{a}$ & 132.1 & $-0.0(-7.9,7.9)$ & $-0.5(-8.5,7.6)$ \\
\hline
\end{tabular}

${ }^{a}$ Mean predicted from fully adjusted regression model

b Adjusted for baseline age, baseline IGF, baseline lifestyle exposure, follow-up time point

${ }^{c}$ Further adjusted for treatment received and cancer grade

${ }^{\mathrm{d}}$ Rounded to the nearest 0.5 times/week

e Baseline smoking status only was evaluated due to minimal change at follow-up. n/a not applicable $* p=0.05, * * p=0.02 * * * p=0.004$ 
reduction of $1.8 \mathrm{~kg} / \mathrm{m}^{2}$ in $\mathrm{BMI}$ ), which is in line with the findings from several studies $[37,38]$.

Our finding of a lower average post-diagnosis IGF-I level in men who reduced their protein intake is supported by most studies, which found a positive link between protein intake and IGF-I [6-8]. The decrease in protein intake in our study may be attributed to a lower intake of dairy products and decreased protein intake from dairy sources. It has been postulated that the protein fraction of dairy (i.e., dairy protein) drives the positive relationship between IGF-I and dairy intake $[8,10,39]$. However, we did not observe any associations of changes in dairy product or dairy protein intake with post-diagnosis IGF-I or IGFBP-3.

Men who adhered to the recommendation on fruits and vegetables ( $\geq 5$ portions/day) post-diagnosis had lower average IGF-I levels than men who were non-adherent and did not change. Similarly, men who were adherent to the recommendation pre- and post-diagnosis had lower IGF-I levels. High vegetable intake has been linked to lower circulating levels of IGF-I or higher IGFBP-3 in some [12, 13, 19] but not all studies [39, 40]. However, IGF-I levels were also lower in men who decreased their intake to fewer than five portions a day after a diagnosis in our study. It is possible that pre-diagnosis diet reflects long-term dietary intake, so long-term adherence to the recommendation on fruits and vegetables may offset the impact of lower fruits and vegetables intake after a diagnosis on circulating IGF-I. Nonetheless, we cannot exclude the possibility of a chance findings in the context of potential misclassification of exposure errors, limited power, and multiple testing.

We did not find any links between changes in lifestyle factors and post-diagnosis IGF-I, except for physical activity. Men who were active before diagnosis but became inactive had higher average post-diagnosis IGF-I levels, but the strength of evidence was weak. Post-diagnosis IGFBP-3 was lower in men who met the BMI recommendation $\left(<25.0 \mathrm{~kg} / \mathrm{m}^{2}\right)$, especially among men who were overweight before diagnosis but acquired a healthy BMI after diagnosis. The positive association between BMI and IGFBP-3 was previously observed in cancer-free men in the ProtecT study [17]. IGFBP-3 increased by $63.5 \mathrm{ng} /$ $\mathrm{ml}$ per SD higher in BMI (95\% CI -2.69-129.8, $p=0.06)$. Conversely, the Coronary Artery Risk Development in Young Adults (CARDIA) study found no association between 8-year changes in BMI and IGFBP-3 [15].

Strengths of our study include its size and populationbased, prospective design. Detection bias was minimized, as case finding was part of the trial design. There were standardized records of cancer stage and grade, and types of treatment. We also have blood samples collected close to the return date of the follow-up questionnaires ( \pm 6 months). However, most participants were White European, and there are some ethnic differences in dietary and lifestyle associations with IGF peptides [15, 19, 41], so our findings may not be generalizable to other ethnic groups.

Although we used validated and detailed questionnaires to minimize measurement error, there will still be some misclassification of exposures. Compared to food diaries, FFQ is prone to a greater degree of misclassification $[42,43]$, but the effect is likely to be non-differential in our study as baseline questionnaires were completed by $54.1 \%$ of men before receipt of initial PSA test results, and men were not given any dietary advice after diagnosis. Therefore, true associations of dietary and lifestyle changes with post-diagnosis circulating IGF-I and IGFBP-3 might be underestimated.

There was variation in baseline and follow-up serum sample storage time, ranging from 0 to 7 years. Nonetheless, storage time was not associated with baseline or follow-up circulating IGF-I and IGFBP-3 in univariable analyses. Finally, using a conservative Bonferroni multiple testing penalty would lead to just one strong finding. However, our study is the first to find such differences in IGF-I and IGFBP-3 post-diagnosis, and other studies are needed to replicate our novel findings. To minimize multiple testing, we had decided a priori on the dietary and lifestyle variables to be tested and used established dietary guidelines and lifestyle recommendations for categorization where available.

In conclusion, decreased protein intake and BMI, and increased fruits and vegetables intake and physical activity, following a prostate cancer diagnosis were associated with reduced post-diagnosis serum IGF-I and IGFBP-3. As one of the first studies to identify these links, our findings warrant confirmation in other studies and may inform future dietary and lifestyle interventions in men with prostate cancer.

Acknowledgments The authors would like to thank all men who took part in the study and the contribution of all members of the ProtecT study research group.

Funding This work was supported by the National Institute for Health Research (NIHR) Bristol Nutrition Biomedical Research Unit. The unit is a partnership between University Hospitals Bristol NHS Foundation Trust and the University of Bristol. ProtecT is funded by the NIHR Health Technology Assessment programme (HTA 96/20/ 99). VE was a recipient of a 3-year PhD studentship at the Bristol Nutrition Biomedical Research Unit from 2012 to 2015. RG is funded by a Cancer Research UK Population Research Postdoctoral Fellowship (C31211/A15194). RMM, JMPH, MJ, JAL, JLD, and FCH are recipients of CRUK programme funding (C18281/A19169).

Authors' contribution RMM, MJ, JAL, JLD, DEN, and FCH designed research; KB performed the IGF assays; VE, JMPH, PE, 
RG, KNLA, MD, and EW prepared the data; VE analyzed the data; VE, AJS, RMM, and JAL wrote the first draft of the paper; JAL, AJS, and RMM provided supervision; VE, AJS, RMM, JMPH, and JAL have primarily responsibility for the final content. All authors read and approved the final version of the paper.

\section{Compliance with ethical standards}

Conflict of interest The authors declare that there are no conflicts of interest.

Disclaimers The views expressed herein are those of the authors and do not necessarily reflect those of Cancer Research UK, the NHS, the NIHR, or the Department of Health.

Open Access This article is distributed under the terms of the Creative Commons Attribution 4.0 International License (http://crea tivecommons.org/licenses/by/4.0/), which permits unrestricted use, distribution, and reproduction in any medium, provided you give appropriate credit to the original author(s) and the source, provide a link to the Creative Commons license, and indicate if changes were made.

\section{References}

1. Yu H, Rohan T (2000) Role of the insulin-like growth factor family in cancer development and progression. J Natl Cancer Inst 92:1472-1489

2. Travis RC, Appleby PN, Martin RM, Holly JMP, Albanes D, Black A et al (2016) A meta-analysis of individual participant data reveals an association between circulating levels of IGF-I and prostate cancer risk. Cancer Res 76:2288-2300

3. Rowlands MA, Holly JM, Hamdy F, Phillips J, Goodwin L, Marsden $G$ et al (2012) Serum insulin-like growth factors and mortality in localised and advanced clinically detected prostate cancer. Cancer Causes Control 23:347-354

4. World Cancer Research Fund, American Institute for Cancer Research (2007) Food, nutrition, physical activity, and the prevention of cancer: a global perspective. AICR, Washington DC

5. Er V, Lane JA, Martin RM, Emmett P, Gilbert R, Avery KNL et al (2014) Adherence to dietary and lifestyle recommendations and prostate cancer risk in the Prostate testing for cancer and Treatment (ProtecT) trial. Cancer Epidemiol Biomark Prev 23:2066-2077

6. Thissen JP, Ketelslegers JM, Underwood LE (1994) Nutritional regulation of the insulin-like growth factors. Endocr Rev 15:80-101

7. Giovannucci E, Pollak M, Liu Y, Platz EA, Majeed N, Rimm EB et al (2003) Nutritional predictors of insulin-like growth factor I and their relationships to cancer in men. Cancer Epidemiol Biomark Prev 12:84-89

8. Crowe FL, Key TJ, Allen NE, Appleby PN, Roddam A, Overvad $\mathrm{K}$ et al (2009) The association between diet and serum concentrations of IGF-I, IGFBP-1, IGFBP-2, and IGFBP-3 in the European Prospective Investigation into Cancer and Nutrition. Cancer Epidemiol Biomark Prev 18:1333-1340

9. Heaney RP, McCarron DA, Dawson-Hughes B, Oparil S, Berga SL, Stern JS et al (1999) Dietary changes favorably affect bone remodeling in older adults. J Am Diet Assoc 99:1228-1233

10. Hoppe C, Molgaard C, Juul A, Michaelsen KF (2004) High intakes of skimmed milk, but not meat, increase serum IGF-I and IGFBP-3 in eight-year-old boys. Eur J Clin Nutr 58:1211-1216
11. Mucci LA, Tamimi R, Lagiou P, Trichopoulou A, Benetou V, Spanos E et al (2001) Are dietary influences on the risk of prostate cancer mediated through the insulin-like growth factor system? BJU Int 87:814-820

12. Probst-Hensch NM, Wang H, Goh VH, Seow A, Lee HP, Yu MC (2003) Determinants of circulating insulin-like growth factor I and insulin-like growth factor binding protein 3 concentrations in a cohort of Singapore men and women. Cancer Epidemiol Biomark Prev 12:739-746

13. Norat T, Dossus L, Rinaldi S, Overvad K, Gronbaek H, Tjonneland A et al (2007) Diet, serum insulin-like growth factor-I and IGF-binding protein-3 in European women. Eur J Clin Nutr 61:91-98

14. DeLellis K, Rinaldi S, Kaaks RJ, Kolonel LN, Henderson B, Le Marchand L (2004) Dietary and lifestyle correlates of plasma insulin-like growth factor-I (IGF-I) and IGF binding protein-3 (IGFBP-3): the multiethnic cohort. Cancer Epidemiol Biomark Prev 13:1444-1451

15. Gapstur SM, Kopp P, Chiu BC, Gann PH, Colangelo LA, Liu K (2004) Longitudinal associations of age, anthropometric and lifestyle factors with serum total insulin-like growth factor-I and IGF binding protein-3 levels in Black and White men: the CARDIA Male Hormone Study. Cancer Epidemiol Biomark Prev 13:2208-2216

16. Morimoto LM, Newcomb PA, White E, Bigler J, Potter JD (2005) Variation in plasma insulin-like growth factor-1 and insulin-like growth factor binding protein-3: personal and lifestyle factors (United States). Cancer Causes Control 16:917-927

17. Rowlands MA, Holly JM, Gunnell D, Gilbert R, Donovan J, Lane JA et al (2010) The relation between adiposity throughout the life course and variation in IGFs and IGFBPs: evidence from the ProtecT (Prostate testing for cancer and Treatment) study. Cancer Causes Control 21:1829-1842

18. Crowe FL, Key TJ, Allen NE, Appleby PN, Overvad K, Gronbaek $\mathrm{H}$ et al (2011) A cross-sectional analysis of the associations between adult height, BMI and serum concentrations of IGF-I and IGFBP-1 -2 and -3 in the European Prospective Investigation into Cancer and Nutrition (EPIC). Ann Hum Biol 38:194-202

19. McGreevy KM, Hoel BD, Lipsitz SR, Hoel DG (2007) Impact of nutrients on insulin-like growth factor-I, insulin-like growth factor binding protein-3 and their ratio in African American and white males. Public Health Nutr 10:97-105

20. Lane JA, Donovan JL, Davis M, Walsh E, Dedman D, Down L et al (2014) Active monitoring, radical prostatectomy, or radiotherapy for localised prostate cancer: study design and diagnostic and baseline results of the ProtecT randomised phase 3 trial. Lancet Oncol 15:1109-1118

21. Willett W (2012) Nutritional epidemiology, 3rd edn. Oxford University Press, New York

22. Godin G (2011) The Godin-Shephard leisure-time physical activity questionnaire. Health Fit J Canada 4:18-22

23. Bingham SA, Welch AA, McTaggart A, Mulligan AA, Runswick SA, Luben R et al (2001) Nutritional methods in the European Prospective Investigation of Cancer in Norfolk. Public Health Nutr 4:847-858

24. Ministry of Agriculture (1993) Fisheries and food (GB). Food portion sizes. HMSO, London

25. Maynard MJ, Blane D (2009) Dietary assessment in early old age: experience from the Boyd Orr cohort. Eur J Clin Nutr 63:S58-S63

26. Holland B, Welch A, Unwin I, Buss D, Paul A, Southgate D (1991) McCance and Widdowson's the Composition of foods, 5th edn. Royal Society of Chemistry (GB), Cambridge

27. Giovannucci E, Ascherio A, Rimm EB, Stampfer MJ, Colditz GA, Willett WC (1995) Intake of carotenoids and retinol in 
relation to risk of prostate cancer. $\mathrm{J}$ Natl Cancer Inst $87: 1767-1776$

28. Scientific Advisory Committee on Nutrition (2015) Public Health England. Carbohydrates and health. London, UK

29. Department of Health (GB). 5 A Day. 2010

30. Cheetham TD, Holly JMP, Baxter RC, Meadows K, Jones J, Taylor AM et al (1998) The effects of recombinant human IGF-I administration on concentrations of acid labile subunit, IGF binding protein-3, IGF-I, IGF-II and proteolysis of IGF binding protein-3 in adolescents with insulin-dependent diabetes mellitus. J Endocrinol 157:81-87

31. Holly JMP, Biddlecombe RA, Dunger DB, Edge JA, Amiel SA, Howell $\mathrm{R}$ et al (1988) Circadian variation of GH-independent IGF-binding protein in diabetes-mellitus and its relationship to insulin. A new role for insulin? Clin Endocrinol 29:667-675

32. Rowlands MA, Holly JM, Gunnell D, Donovan J, Lane JA, Hamdy $\mathrm{F}$ et al (2012) Circulating insulin-like growth factors and IGF-binding proteins in PSA-detected prostate cancer: the large case-control study ProtecT. Cancer Res 72:503-515

33. Vickers AJ, Altman DG (2001) Statistics notes-analysing controlled trials with baseline and follow up measurements. BMJ 323:1123-1124

34. Barnett AG, van der Pols JC, Dobson AJ (2005) Regression to the mean: what it is and how to deal with it. Int $\mathrm{J}$ Epidemiol $34: 215-220$

35. Chan JM, Holick CN, Leitzmann MF, Rimm EB, Willett WC, Stampfer MJ et al (2006) Diet after diagnosis and the risk of prostate cancer progression, recurrence, and death (United States). Cancer Causes Control 17:199-208

36. Satia JA, Walsh JF, Pruthi RS (2009) Health behavior changes in White and African American prostate cancer survivors. Cancer Nurs 32:107-117

37. Karlsen RV, Bidstrup PE, Christensen J, Larsen SB, Tjonneland A, Dalton SO et al (2012) Men with cancer change their health behaviour: a prospective study from the Danish Diet, Cancer and Health Study. Br J Cancer 107:201-206

38. Demark-Wahnefried W, Peterson B, McBride C, Lipkus I, Clipp E (2000) Current health behaviors and readiness to pursue lifestyle changes among men and women diagnosed with early stage prostate and breast carcinomas. Cancer 88:674-684

39. Holmes MD, Pollak MN, Willett WC, Hankinson SE (2002) Dietary correlates of plasma insulin-like growth factor I and insulin-like growth factor binding protein 3 concentrations. Cancer Epidemiol Biomark Prev 11:852-861

40. Tran CD, Diorio C, Berube S, Pollak M, Brisson J (2006) Relation of insulin-like growth factor (IGF) I and IGF-binding protein 3 concentrations with intakes of fruit, vegetables, and antioxidants. Am J Clin Nutr 84:1518-1526

41. Colangelo LA, Chiu BC, Liu K, Kopp PA, Gann PH, Gapstur SM (2005) IGF-1, IGFBP-3, and nutritional factors in young black and white men: the CARDIA Male Hormone Study. Nutr Cancer 53:57-64

42. Bingham S, Luben R, Welch A, Low YL, Khaw KT, Wareham N et al (2008) Associations between dietary methods and biomarkers, and between fruits and vegetables and risk of ischaemic heart disease, in the EPIC Norfolk Cohort Study. Int J Epidemiol 37:978-987

43. Bingham SA, Gill C, Welch A, Day K, Cassidy A, Khaw KT et al (1994) Comparison of dietary assessment methods in nutritional epidemiology: weighed records v. $24 \mathrm{~h}$ recalls, food-frequency questionnaires and estimated-diet records. Br J Nutr 72:619-643

44. Epstein JI, Allsbrook WC, Amin MB, Egevad LL, Committee IG (2005) The 2005 International Society of Urological Pathology (ISUP) Consensus Conference on Gleason Grading of Prostatic Carcinoma. Am J Surg Pathol 29:1228-1242 